\title{
Linguistic Identity with Special Reference to Western Hindi Dialects
}

Pallav Vishnu

Assistant Professor(Contractual) Department of Linguistics A.M.U.Aligarh-202001(U.P.) India

email: pallavvishnu.amu@gmail.com

Received:

February 03, 2021

Revised:

March 17, 2021

Accepted:

May 25, 2021

\section{ABSTRACT}

Linguistic identity is the common bond that people share when they can understand each other in their native tongues, even if they share no other common heritage. Linguistic identity gets trickier when you're talking about two people who may share linguistic bonds but come from mutually hostile ethnic groups. With racial and ethnic identity, linguistic identity does not exist in isolation; it is frequently yet one more facet of how a person identifies. There's what we might call "reverse linguistic identity." As Boas demonstrated over a century ago, everyone has at least three independent identities: race (in the traditional, not the anthropological sense), culture, and language. Language (or linguistic) identity take to mean the speech community with which someone is identified. This is probably always a historical phenomenon, either of birth or of personal choice. Most subjects to personal choice are culture and language, for instance, a given person identifies with, or belongs to a particular culture, and speaks a particular language. These identities may be due to birth or socialization, or they may be the result of a deliberate choice NOT to identify with the language and culture of birth. Linguistic identities are double-edged swords because, while functioning in a positive and productive way to give people a sense of belonging, they do so by defining an "us" in opposition to a "them" that becomes all too easy to demonize. All identity markers of a social group together constitute the "culture" or cultural identity of the social group. Therefore, the loss of one marker does not automatically entails the loss of cultural identity. Given the rich multilingual tradition of India where languages act as facilitators rather than as barriers in communication, one hopes that as linguistic identity. This paper is a case study of the author's inferences regarding the Western Hindi dialects analysis.

Keywords: Linguistics; Special Identity; Western Hindi Dialect

\section{INTRODUCTION}

Let us start the analysis with the children's response towards dialectal acquisition rather than the language at the initial level itself.

The linguistic diversity enduring beyond institutional pressures and social prejudices against non-standard dialects questions the social forces influencing language maintenance across generations and how children contribute to this process. Children encounter multi-dialectal interactions in their early environment, and increasing evidence shows that the acquisition of sociolinguistic variation is not a side 
issue but an inherent part of the general acquisition process. Despite these recent advances in sociolinguistic acquisition, children's sociolinguistic uses remain understudied in relation to peer social networks and the ability to use dialect for identity purposes.

The target children were recorded during spontaneous dyadic conversations during free play at school with each category of friends. Target boys, but not girls, used the regional variant significantly more frequently with their long-term native friends than with their non-native friends. This adjustment mirrored their partners' uses. Moreover, with long-term native friends, boys used the regional variant twice as frequently as girls. Boys appeared thus as key actors in the maintenance and the diffusion of regional cues in local social networks.

The linguistic diversity enduring beyond institutional pressures and social prejudices against non-standard dialects (i.e., through national language policies, school, media, as well as stigmatization and negative social judgments) questions the social forces underlying dialect maintenance across generations and how children contribute to this process (Chambers and Trudgill, 1998; Chambers, 2003).

Most humans carry regional and social markers from their native community. These markers have a local adaptability, namely significance for local identity and relationships, within local social networks in particular (Chambers, 2003). A number of studies have investigated the relationship between language uses and social network structure in adults and adolescents. These studies all point in the same direction: the more individuals are integrated in their local social network, the more they show the typical uses of their community or their peer group (see Labov, 2001; Milroy, 2002 for reviews). This influence of social networks has been evidenced at various linguistic levels, from sounds to syntactic constructions, in a variety of communities, both urban and rural.

In urban communities, Milroy (1980) seeking in the neighborhood of Belfast in Northern Ireland, what makes working class speech local, found a relationship between the use of local vernacular varieties and the density (i.e., contacts are interconnected) and multiplexity (i.e., interacting with the same people in a variety of contexts) of men's working class social networks. Labov (2001) provided a similar account for Philadelphia suburban neighborhoods. The social trajectories were also observed in small rural communities where the local regional dialect competed with the standard linguistic varieties.

\section{METHOD}

This paper is a case study of the author's inferences regarding the Western Hindi dialects analysis. Taken together, the studies conducted with adults or adolescents in various linguistic and social settings present nevertheless convergent evidence that speakers with strong ties within the local community maintain their local dialects more vigorously than others. Close-knit networks appear thus as an important mechanism in dialect maintenance. The studies also revealed that, at least in some communities and for some linguistic variables, uses of the local dialect are age-graded and gendered, the 
oldest men showing the highest uses of vernacular varieties, suggesting a different role of age groups across generations and genders in dialect conservatism. This leads us to question the contribution of younger speakers as children's dialectal uses remain understudied in relation to peer social networks and the ability to use dialect for identity purposes.

\section{FINDINGS AND DISCUSSION}

Children encounter multi-dialectal interactions in their early environment, and increasing evidence shows that the acquisition of sociolinguistic variation is not a side issue but an inherent part of the general acquisition process taking place first in the family.

Empirical evidence of the influence of peer group has been provided by studies of speakers moving to a new dialectal area and children's subsequent second dialect acquisition. In a number of cases, children do not speak like their parents, but instead follow the patterns of their peers (Chambers, 2002). As described above for adults and adolescents, a child's integration into the local peer group is crucial in determining whether she or he adopts the local dialect feature (e.g., Labov, 1972b; Kerswill and Williams, 2000). The influence of other children and peers outside the family has been more rarely studied in first dialect acquisition. Nevertheless, one study investigated the relationship between children's uses and peer social network showing that the preschool children who interact more frequently in the classroom adopt similar uses of non-standard varieties leading to a convergence in children's uses over a school year (Nardy et al., in press). Thus, peer social interactions influence children's dialectal uses at an early age and appear as an important piece of the puzzle to understand the social dynamics of dialect maintenance or change.

Although family plays a primary role in first dialect acquisition and transmission, children also go to school at an early age and there they are in extended contact with peers potentially from other social or geographical backgrounds. This leads us to question what children are doing socially with linguistic variation within peer networks and how they are using local varieties during face-to-face interactions, in particular with friends. Although stylistic variation and accommodation to the interlocutor have been well described in adults, their emergence and development during childhood remain poorly documented.

Language is fundamentally variable, not only within the speech community but also in the speech of an individual; this intraspeaker variation related to social context is referred to as stylistic variation (Labov, 1972b; Coupland, 2007). The frequency with which an adult speaker uses standard and non-standard variants depends on the social context of the exchange influencing the stylistic choices of the speaker (Chambers et al., 2002). These contextual factors range from the situational context of speech (e.g., formal vs. casual) to the topic of conversation and the identity of the addressee (Labov, 1972b; Rickford and McNair-Knox, 1994). Notably, speakers can modify their linguistic uses to match those of their interlocutors during exchanges. In one of the most comprehensive studies on speakers' accommodation in a natural setting. 
Now concentrating on Western Hindi dialects as major identity feature for people of western U.P. and other areas where these dialects are spoken freely.

\section{Western Hindi Dialects:}

About 500 million people speak Hindi, in India and abroad, and the total number of people who can understand the language may be 800 million. According to 2011 survey the data also shows Hindi has added about 10 crore speakers between 2001 and 2011 found HINDI 52,83,47,193 that 43.63\% of all Indians can speak Hindi and remaining Indians regard Hindi as "one language across the nation". More than 180 million people in India regard Hindi as their mother tongue. Another 300 million use it as second language.

\section{Regional Variation}

\section{Khadiboli}

Khadiboli (also Khadiboli or khari dialect) is a dialet of Hindi language, spoken in Western Uttar Pradesh. It is the variation of Hindi language that is used by the Indian state. The earliest examples of Khadiboli can be seen in some of Kabir and Amir Khusro's lines. More developed forms of Khadiboli can be seen in some mediocre literature produced in early 18th century. Examples are Chand Chhand Varnan Ki Mahima by Gangabhatt, yogavashishtha by Ramprasad Niranjani, GoraBadal ki katha by Jatmal, Mandovar ka varnan by Anonymous, a translation of Ravishenacharya's Jain Padmapuran by Daulatram (dated 1824). In 1857, East India Company established Fort William College at Calcutta. The College President John Gill Christ hired professors to write books in Hindi and Urdu. Some of these books were Premsagarby Lalloolal, Naasiketopaakhyan by Sadal Mishra, Sukhsagar by Sadasukhlal of Delhi and Rani Ketaki ki kahani by Munshi Inshallah Khan. The language of these books can be called Khadiboli.

Khadiboli was a rural language in its early days. But after 18th century, people started using it as the literary form of Hindi. Its vocabulary has a large amount of Persian and Arabic words, but it is heavily Sanskritized as well. In its original form, it is spoken in Rampur, Moradabad, Meerut, Bijnor, Mujjafarnagar, Saharanpur, Dehradun, Ambala, Patiala and Delhi. Almost all the significant modern Hindi literature has been produced in Khadiboli.

\section{Braj}

Braj, though never a clearly defined political region, is considered to be the land of Krishna and is derived from the Sanskrit word vraja. Thus, Brajbhasa is the language of Braj and it was the language of choice of the Bhakti movement, or the neoVaishnavite religions, the central deity of which was Krishna. Therefore, most of the literature in this language pertains to Krishna composed in medieval times. 
Brajbhasa, or Brajavali was adapted to the Assamese language by Srimanta Sankar deva for his compositions in the 15th and 16th century in Assam. Brajbhasha is a dialect of Hindi Language, spoken in Uttar Pradesh. Brajbhasa is spoken in Mathura, Vrindavana, Agra, Aligarh, Bareli, Bulandhshahar and Dhaulpur. It has a very sweet tone. Much of the Hindi literature was developed in Braj in the medieval period. However, today Khari dialect has taken its place.

\section{Bundeli}

Bundeli is a dialect of Hindi spoken in the Bundelkhand region of Madhya Pradesh and Jhansi in Uttar Pradesh. In medieval period, some literature was available in this language, but most of the speakers preferred Braj as the literary language.

\section{Hariyanavi (Bangaru or Jatu)}

Hariyanavi or Jatu or Bangaru is a dialect of Hindi language, spoken in Haryana. It is spoken by Jats in Haryana and Delhi. It can be considered as a variation of the early Khadiboli. It has somewhat harsh tone. The literature is almost nil, but there are a lot of folk songs available.

Some of the East-Central Zone languages, including and Dhanwar and Rajasthani languages, including Marwari, are also widely considered to be dialects of Hindi. There has been considerable controversy on the status of Punjabi and the Bihari languages, including Maithili, Bhojpuri and Magadhi.

\section{Kannauji:}

Kannauji is spoken in the districts of Kannauj, Farukkhabad, Hardoi, Shahjahanpur, Pilibhit, Itavah and western parts of Kanpur in Uttar Pradesh. Its sub dialect is Tirhari.

\section{d) Generation:}

i) Older generation

ii) Younger generation

At the level of lexical choice, age variable as a linguistic factor has some effect. For instance, the older generation resorted to Internal code - mixing (from various dialects of Hindi, e.g. Braj, Awadhi, Bhojpuri etc.)

1) hamāre lige panvā (pān)le ānā.

2) rotiyā (rotī) jal gaȳì.

The younger generation prefers external code mixing/ code switching.

1) Meri sister-in-law aaj subah ki flight se āyī.

2) Aunty, mein kis time āūn

But any significant variation among the generations cannot be noticed. 


\section{Social variation - b) Gender}

Work on women's language over the last few decades has shown that women's language is closer to the standard prestige variant than the men's language, the reason being women's linguistic insecurity due to their subordinate position in society. Usually men's speech is the norm and women's speech is judged against this. This is true of Hindi also. Usually, women's speech is marked by an expression that is more polite.

main khāna khākar bāhar

jāūngā (men's speech)

dekhen, shāyad mujhe bāhar jānā

hoga (women's speech)

Some slang expressions used almost exclusively by women are -

$\begin{array}{ll}\text { muhjhaunsā } & \text { (burnt }- \text { faced) } \\ \text { muhjhaunsī } & \text { (burnt }- \text { faced) } \\ \text { muhjalī } & \text { (ill }- \text { lucked) } \\ \text { muhjalā } & \text { (ill }- \text { lucked) } \\ \text { kulbornī } & \text { (one who brings shame upon the family) }\end{array}$

\section{(c) Education:}

The society is stratified on the basis of various factors including education. The educational background of a person causes an important linguistic variable. The diglossic situation in Hindi is evident when these social factors are taken into consideration. The sanskritized 'High Hindi' that became the vehicle of official discourse after independence created a destination between ordinary conversation and official communication. The educated sections of society had access to the standard language used on formal occasions. This language became the symbol of power and upward mobility. The educated speakers have no regional traits in their language while speaking the language in a formal situation. Speech can thus indicate the educational background of a person. Because of these factors, a speaker many be more familiar in terms of language to people from the same social group in different areas than to speakers from a different social and educational background in the same geographical area.

\section{Social Variation - a) Caste}

\section{1) Sub-Caste Variation}

There are differences in language of various castes and sub-caste groups. These constitute the non-regional differences in a language and are referred to as social 
dialects or sociolects. Caste is a social factor that has a role in distinguishing between a standard and a non-standard-dialect. Accent and dialect many act as indicators of one's caste group. The members of the caste group at the top of the social ladder, i.e., Brahmins typically speak the standard variety. It has been surmised that members of this caste group has access to better organized speech. E.G. Maithili is spoken in its purest form by the Brahmins of the north of Darbhanga and Bhagalpur districts and Western Purnia.

Some of the castes and Sub-castes are trade and industry specific and the registers used by them are also specific to their profession, e.g., Agarwal, Baranwal, Bhatiya, Khattri, Oswal, Dhunia, Julaha, Kahar, Lohar, Nai, Mochi, Pasi, Sonar, Teli, Thathera, Halwai, Kalwar, Khatik, tamboli, Nanbai, Bhisti etc.

In 1958, Gumperz had described how linguistic variation is related to social variation in the village of Khalapur, eighty miles north of Delhi. The social structure of the village was marked by Caste-group membership, e.g. the speech of the Bhangis did not have the phonological contrast that the speech of the other castes have. The attempt of some castes to emulate the other castes resulted in hypercorrection. Gumperz's study shows a direct relationship between linguistic variation and castegroup membership. However, the modern Indian society is far more complex and complicated. Establishing the relationship of caste and linguistic variation has also become more complex.

\section{(ii) Sub-tribe Variation:}

The Linguistic connotation of the term 'tribal' in tribal languages takes into account linguistic contacts, contacts, convergences and bilingualism. Tribal bilingualism is a part of the process of tribal assimilation into the mainstream, e.g., tribal belts of the central areas of the country are interspersed with non-tribal areas. The tribal languages in this area serve primarily as a vehicle of tribal identity. This area is marked by linguistic contacts and convergences. As a consequence, there is a tendency of shifting from tribal languages to the non-tribal dialects (chiefly dialects of Hindi) in these states, i.e., Madhya Pradesh, Chattisgarh, Rajasthan etc.

In these states, there is high incidence of bilingualism among tribal language speakers. A chief characteristic of tribal bilingualism is its instability, due to the exposure to other communities and the resulting process of acculturation. As a consequence, decreasing number of tribals are returning the tribal language as their mother tongue. Thus the phenomenon of language shift is visible in this area. According to the 1981 census, only $37 \%$ of all tribals speak a tribal mother tongue. Some of the tribal communities in these states who are bilingual and speak a dialect of Hindi are Baiga (Madhya Pradesh), Bharia (Madhya Pradesh), Bathudi (Bihar), Bhoksa (Uttar Pradesh), Binjhwar (Maharashtra), Dhanka (Rajasthan), Dhanwar (Madhya Pradesh) Gond Khatola, Gond (Madhya Pradesh) Kamar (Chattisgarh), Kawar (Chattisgarh), Kol (Maharashtra and Madhya Pradesh), Korwa (Chattisgarh) Majhwar (Chattisgarh), Mawasi (Madhya Pradesh), Panika (Madhya Pradesh) 
Sahariya (Madhya Pradesh), Saur (Madhya Pradesh) Lamani Banjari (Rajasthan) Khotta, Sadan, Gawari Panchparganis (Bihar).

\section{Diglossia:}

Hindi is marked by the classic situation of diglossia, i.e., the presence of two distinct varieties of which one is used only on formal and public occasions which the other is used under normal everyday circumstances. The Indian society is multilingual and stratified. The situation of Hindi is more complex than the other regional languages because besides the basic style, there are two superimposed styles in Hindi. The basic style is the language used in day-to-day life and the superimposed styles are, the artificially sanskritised (or High Hindi) language, and 'Urdu', a distinct version of Hindustani characterized by a large number of persionised words.

Hindi, the language of everyday life that has evolved in North India is a heteroglot, hybrid language that has assimilated the resources of its many dialects. The chasm between this Hindi/Hindustani and Urdu goes back to the early nineteenth century when the idea of two languages was created by colonial intervention, one divested of Persian - Arabic repertoire and the other full of it. Later language and script came to be seen as markers of religions identity. Thus a vernacular with two variations, drawing sustenance from two resources came into being, inspired by communal politics.

After independence, the question of a common language of communication and official discourse was debated by the constituent assembly and the language subcommittee of the constituent assembly recommended that Hindi be the first official language of the union. But the ideologues of Hindi tried to substitute the people's vernacular 'Hindustani' with a "Rashtrabhasha Hindi" that was characterized by a Sanskrit laden style. This Sanskritised High Hindi became the vehicle of official discourse and written literature but is not used by any section of community for ordinary conversation. Official Hindi created a distinction between high and popular discourse by becoming the symbol of power and upward mobility.

The people's vernacular is characterized by its borrowings from multilingual sources, flexibility and vast geographical area. The various dialects in this Vernacular are interrelated in a complex way and are overlapping. The verbal repertoire of Hindi includes the various dialects of Hindi (i.e., Awadhi, Braj, Bundeli, Bagheli, Chhattisgarhi, Rajasthani, Kannauji, etc.) as well as the two superimposed styles. These dialects and registers are interrelated in such a complex way that code-switching takes place spontaneously. At different social levels, the complex relations between these styles and dialects are manifested in different ways. In formal situations and due to social pressures, there is code-switching between the Vernacular Hindustani and the Sanskritised Hindi. At a different level, internal code-switching between Hindustani and the various dialects take place due to social pressures. To understand this complex diglossic situation present in Hindi, it is important to understand the relationships 
between the verbal repertoire, code matrix and code-switching in Hindi in various contexts and situations.

\section{Register/Stylistic/Code:}

Because of the concerted effort to evolve scientific and technical terminology in Hindi, basic pan-Indian terminology pertaining to various disciplines was evolved.

\section{Judiciary:}

Some of the Hindi terms in the field of Judiciary are:

$\begin{array}{ll}\text { nyāyapālikā } & \text { (judiciary) } \\ \text { nyāyālaya } & \text { (court) } \\ \text { nyāya-vyavastha } & \text { (judicial system) } \\ \text { āparādhik-nyāyālaya } & \text { (criminal court) } \\ \text { senā-nyāyālaya } & \text { (court marshal) } \\ \text { uccha nyāyālaya } & \text { (high court) } \\ \text { ucchatam nyāyālaya } & \text { (supreme court) } \\ \text { nyāyādhīsha } & \text { (judge) } \\ \text { nyāyamūrti } & \text { (justice) } \\ \text { mukhya nyāyamūrti } & \text { (chief justice) }\end{array}$

\section{Medical:}

Some of the terms that are used in the field of medicine are following:

àyurvigyān

sankrāmak rog

mahāmārī

sankraman

rog nidān

jwar-māpī

prākritic chikitsā

chikitsakīya visheshagya

āpāt chikitsā

tatkāl chikitsā

strīrog chikitsā

shishu chikitsā

shalya chikitsā

asthi chikitsā

chikitsālaya

aushadhālaya

chikitsak

vakīl

mahādhivaktā

notari public

mukadma (medical science)

(infections disease)

(epidemic)

(infection)

(medical check-up)

(thermometer)

(naturopathy)

(medical expert)

(emergency)

(first-aid)

(gyneacology)

(paedeatrics)

(surgery)

(orthopaedics)

(hospital)

(dispensary)

(doctor)

(lawyer)

(advocate general)

(court-case) 


$\begin{array}{ll}\begin{array}{l}\text { abhiyukta } \\ \text { mahābhiyoga }\end{array} & \begin{array}{l}\text { (accused) } \\ \text { (Impeachment) } \\ \text { ārop-patra }\end{array} \\ \text { prativād } & \text { (charge-sheet) } \\ \text { (defence) } \\ \text { ap̄il } & \text { (appeal) } \\ \text { yāchika } & \text { (petition) } \\ \text { saman } & \text { (summon) } \\ \text { jirah } & \text { (cross examination) } \\ \text { sākshya } & \text { (witness) } \\ \text { naiyāyik niptārā } & \text { (disposal) } \\ \text { khariji } & \text { (dismissal) } \\ \text { bhāratīya vidhi } & \text { (Indian law) } \\ \text { danda samhitā } & \text { (Penal code) } \\ \text { vidhi visheshagya } & \text { (law expert) }\end{array}$

\section{Educational:}

In the field of education, the terminologies commonly used are:

dikshānta - samāroha

(convocation)

shikshā-vibhāga

(education department)

chātrāvās

(hostel)

shikshan

(teaching)

prashikshan

(training)

prashikshu

(apprenticeship)

shaikshanik

(pertaining to education)

prashikshit

(trained)

adhyetā

(student)

pāthyakrama

(course)

pāthyapustak

(text-book)

pāthyavishaya

(subject)

shikshakīya pravacan

(lecture)

adhyayan-satra

(term)

parīkshā

(examination)

maukhik parīkshā

(oral examination)

prashnapatra

(question-paper)

parīkshak

(examiner)

parīkshārthī

(candidate)

nirīkshak

(invigilator)

purnānk

(full marks)

parīkshā - phal

(result)

uttīrna

(pass)

shikshā upādhi

(degree)

snātak upādhi

(Bachelor's degree)

nishnāat

(Masters) 


pramānpatra
kulpati
upa-kulpati
pradhan-adhyāpak
sahpāthī
karmachārī
kānūn aur vyavasthā
kārmic vibhāg
kāryabhār grahan
kārya samiti
kāryālaya
kendra
gopanīya
ghoshan̄̄a patra
tadartha
tarakkī/podonnati
tabādalā
nāgarik adhikār
nāmankan
niyamāvali
niyukti
nilambit

(Certificate)

(Chancellor of a University)

(Vice-chancellor)

(Principal)

(Class-fellow)

(employee)

(law and order)

(personnel section)

(assumption of charge)

(working committee)

(office)

(centre)

(confidential)

(manifesto)

(ad hoc)

(promotion)

(transfer)

(civil rights)

(nomination)

(manual)

(appointment)

(suspended)

\section{Administrative:}

Some of the terms in the field of administration are :

$\begin{array}{ll}\text { prashāsakīya vibhāg } & \text { (administrative department) } \\ \text { kārarvāȳ̄ } & \text { (action) } \\ \text { antarim ādesh } & \text { (interim order) } \\ \text { antardeshīya } & \text { (inland) } \\ \text { akhil bhāratīya seva } & \text { (All India Service) } \\ \text { agrim } & \text { (advance) } \\ \text { atirikta prabhār } & \text { (additional charge) } \\ \text { adhikārī } & \text { (bureaucrat/officer) } \\ \text { adhikaārī tantra } & \text { (bureaucracy) } \\ \text { adhiniyam } & \text { (act) } \\ \text { adhīnastha } & \text { (subordinate) } \\ \text { adhisūchanā } & \text { (notification) } \\ \text { adhyaksha } & \text { (President) } \\ \text { anudān } & \text { (grant) } \\ \text { anubandha } & \text { (agreement) } \\ \text { rājpatra } & \text { (gazettee) } \\ \text { asthāȳi niyukti } & \text { (temporary appointment) } \\ \text { ādhikārik patrāchār } & \text { (official correspondence) }\end{array}$


varishthatā kram

ām chunāv

āyog

ārakshan (order of seniority)

(general election)

(commission)

(reservation)

\section{Religious:}

Some of the terms used in the field of religion are:

dharmagrantha
dharma-parivartan
dharma-prachār
dharma-upadeshak
dharma-pravartak
purohit-karma/yajmānī
upāsana sthal
vedī
upavās
bhakti
āstik
nāstik
adhyātmik

(religious scripture)

(religious conversion)

(propagation of religion)

(religious preacher)

(prophet)

(priest)

(place of worship)

(atter)

(fasting)

(devotion)

(theist)

(atheist)

(spiritual)

\section{Literary:}

In the field of literature, some commonly used terms are:

sahitya

vyākaran

(literature)

vyangakār

(grammar)

gadyakār

(satirist)

nibandhakār

(prose-writer)

kathākār

(essayist)

upanyāskār

(fiction-writer)

jīvanī lekhak

(novelist)

kavi

(biogra)

gītkār

(poet)

nātakkār

(lyricist)

(playwright)

rāshtra kavi

(poet laurate)

sāhityik kriti

(literary work)

lok kathā

(folk tale)

sansmaran

(memoir)

ātmakathā

chandabaddha kāvya

(autobiography)

chandramukta padya

(verse)

gìt

(free verse)

chanda

(lyric)

(meter) 
kāvyashastra

(poetics)

\section{Scientific:}

Some technical terms used in the field of science and technology are:

\begin{tabular}{|c|c|}
\hline vigyān & (science) \\
\hline anusandhān & (research) \\
\hline āvishkār & (invention) \\
\hline prayogshālā & (laboratory) \\
\hline prayog & (test) \\
\hline pramānu & (atom) \\
\hline rasāyana & (chemical) \\
\hline amla & (acid) \\
\hline rasāyanashāstra & (chemistry) \\
\hline kshār & (alchali) \\
\hline khanij & (mineral) \\
\hline ūrjā & (energy) \\
\hline sthitij ūrjā & (static energy) \\
\hline tāpmān & (temperature) \\
\hline tāpānka & (degree) \\
\hline himanka & (frazing point) \\
\hline galanānka & (melting point) \\
\hline vātānukūlit & (air-conditioned) \\
\hline ūtak & (tissue) \\
\hline nābhikīya & (nuclear) \\
\hline koshikā & (cell) \\
\hline harmon & (harmone) \\
\hline prakash parāvartan & (reflection) \\
\hline sampunjan & (focus) \\
\hline dhvani vistāran & (sound amplification) \\
\hline dhvanirodhak & (sound insulator) \\
\hline vāyumāpī & (airmetre) \\
\hline varshāmāpī & (rain gaze) \\
\hline svanamāpī & (sonometre) \\
\hline prakāshmāpī & (lightmetre) \\
\hline gurutvākarshan & (gravitation) \\
\hline bhārhīntā & (weightlessness) \\
\hline chumbatīya bal & (magnetic power) \\
\hline antariksha vigyān & (space science) \\
\hline
\end{tabular}

Words which have gained world-wide usage, e.g., Radio, Radar, Petrol etc., terms based on proper names, e.g., Fahrenheit scale, Voltmeter, Ampere etc., names of elements and compounds e.g., Oxygen, nitrogen, chlorine, hydrogen, ozone etc., binomial nomenclature in such sciences as Botony, Zoology etc., units of weights, 
measures and physical quantities, e.g., Calorie, ampere, etc., and numerals, symbols, signs and formulae e.g, Sin, Cos, Tan, Log, etc., are used in their current English forms.

\section{CONCLUSION}

Grierson (1906) has divided Hindi into two groups: Eastern Hindi and Western Hindi. Between the Eastern and the Western Prakrits there was an intermediate Prakrit called Ardhamagadhi. The modern representative of the corresponding Apabhamsa is Eastern Hindi, and the Chaurasia Apabhramsa of the middle Doab is the parent of Western Hindi. In the Eastern group, Grierson discusses three dialects: Awadhi, Bagheli, and Chhattisgarhi. In the Western group, he explains five dialects: Hindustani, Braj Bhasha, Kanauji, Bundeli, and Bhojpuri. The Hindi region is traditionally divided into two: Eastern Hindi and Western Hindi. The main dialects of Eastern Hindi are Awadhi, Bagheli, and Chhattisgarhi. The Western Hindi dialects are Haryanvi, Brajbhasha, Bundeli, Kanuji, and Khariboli. The dialects are spoken in the regions of Bihar (i.e., Maithili, Bhojpuri, and Magahi), Rajasthan (i.e., Marwari, Jaipuri, Malvi, etc.) and some dialects spoken in the northwestern areas of Uttar Pradesh, and Himachal Pradesh were kept away from the earlier classification. Now, all of these dialects are also covered under the term Hindi.

Hence, the author with full strength can say that Hindi language and especially Western Hindi Dialects do withstand a big identity for all the speakers of these dialects wherever they move or go, without any hesitation.

\section{REFERENCES}

Anderson, B. (1991). Imagined communities: reflections on the origin and spread of nationalism. London: Verso.

Anonimous. An introduction to Hindi language. Department of Linguistics College of Liberal Arts \& Sciences: Illinois.

Bucholtz, M. (2003). Sociolinguistic nostalgia and the authentication of identity. Journal of Sociolinguistics.

Chambers. (2003). Sociolinguistic theory: linguistic variation and its social significance, Wiley: Blackwell.

Chambers and Trudgill. (1998). Dialectology. Cambridge:Cambridge University Press.

Fishamn, J. (Ed.). (1999). Handbook of language and ethnic identity. Oxford: Oxford University Press.

Joseph E. John. (2006). Linguistic identities: Double-edged swords, in language problems and language planning. University of Edinburgh.

Labov, William. (2001). Principles of linguistic change, social factors. Wiley: Blackwell. 
Ronald K.S,. Macualay. (2009). Quantitative methods in sociolinguistics. New York: Palgrave Macmilan.

Vishnu,Pallav. (2013). Paschimi Hindi ki boliyon ka lok-sahitya: ek sankalan, New Delhi: Bahri Publications.

Vishnu, Pallav. (2012). Socio descriptive study of the dialects of Western Hindi. New Delhi : Bahri Publications 